\title{
「細菌時計」が一斉に鳴り響く
}

\section{Bacterial clocks chime in unison}

ERIKA CHeCK HAYdEN 2010 年 1 月 20 日 オンライン掲載

www.nature.com/news/2010/100120/full/news.2010.21.html

\section{人工の遺伝子回路を用いて細菌コロニー全体の時計を合わせる。}

多数の細菌が同調して時を刻む「細菌時 計」が、カリフォルニア大学サンディエ ゴ校（米国）の Jeff Hasty らにより作 製された。この成果は合成生物学を一歩 前進させるものであり、医薬を定期的に 一定量投与する体内埋め込み型の薬剤 ディスペンサーの開発にいずれ結びつく ことだろう。

これまで作られていたのは、細胞 1 個のみで発振する単一細胞振動子だっ た。振動子とは、ある特定の活動を周期 的なスケジュールで害行し、時間を計測 できるデバイスである。

「同一集団内の各個体の振動子を同調 させることができたのは、今回が初めて です」と、チューリッヒ工科大学(スイス・ バーゼル) の Martin Fussenegger はい う。「これがもし哺乳類の細胞で実現で きたら、将来の研究や技術に多大な影響 を与えることでしょう」と話す。

Nature 2010 年 1 月 21 日号に発表 されたこの研究 ${ }^{1}$ では、2 種類の細菌由 来のクオラムセンシング (菌体密度感 知）とよばれる天然の細菌コミュニケー ション機構の一部を担う遺伝子を、大腸 菌のゲノムへ導入した。これらの遺伝子 は 1 個の回路として「配線され」、遺伝 子の 1 つがアシル - ホモセリンラクトン (AHL) というシグナル分子を産生する ように設計された。産生された AHL は 細胞外に拡散し、ほかの細胞に AHLを さらに産生させる。ただしこの回路は、 AHL が同時に、それ自身の分解を招く 別の遺伝子を活性化させるような設計 にもなっている。

これらの相反する正と負のフィード
バックループが、時計の振り子のよう な役目をして、細菌コロニーでの AHL 生産量が規則正しい周期で増減を繰り 返すように調整するのだと、研究チー ムは述べている。今回の回路には、蛍 光リポータータンパク質をコードする 遺伝子が組み込まれており、AHL 産生 量が増えるほど蛍光の明るさが増すの で、大腸菌集団が同調して AHL 産生量 を増減させるようすを観察することが できる。

\section{生活リズム}

Hasty らの系では、マイクロ流体デバイ ス上に細菌が置かれ、デバイスには微小 チャネルがあって、細菌へ栄養素を送り、 老廃物を洗い流せるようになっている。 研究チームは、同調した時計の発振の夕 イミングや強さは、栄養素や老廃物がデ バイスのチャネルを通じて出入りする速 度に依存していると報告している。

研究チームは、このデバイスを開発す るまでに何度も失敗を重ねた。実験を夜 通し行って初めて、構築したクオラムセ ンシング回路の活性化に必要な細菌密 度になるまでには、一定の時間がかかる ことがわかった。さらに Hasty は、「発 振機構を支えることができ、なおかつ流 体を使って AHL 分子を運び去れる程度 の細胞総数を受容できるデバイスを作 り上げる必要がありました。AHL 分子 は自然に分解することはないからです」 と説明する。

Hastyによれば、同調する細菌時計の 開発によって、細菌を生物学的センサー として使えるようになるだろうという。

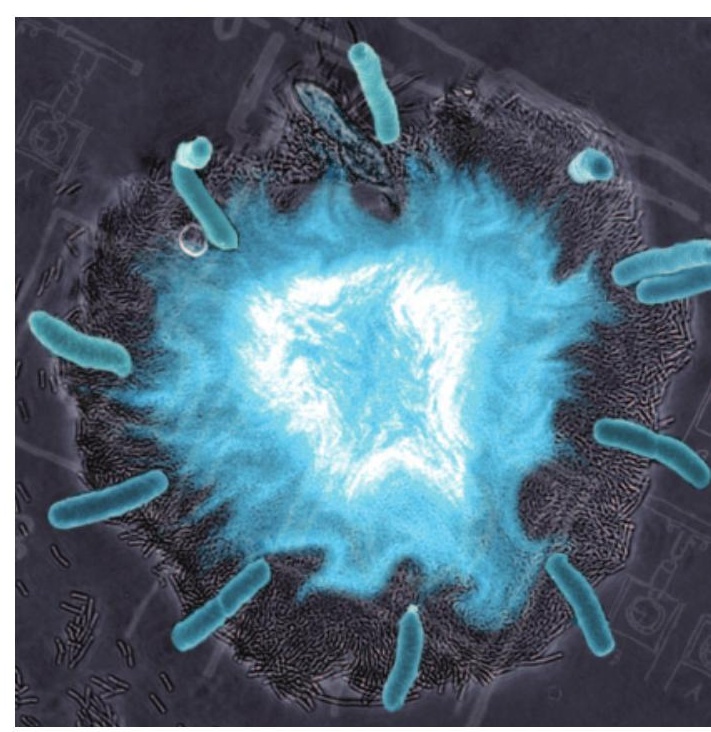

同調した遺伝子時計をもつ細菌のコロニーが 発する強い蛍光。

また Fussenegger は、生物学的リズム の解明にも役立つだろうと話す。人体 のさまざまな活動にも、細胞間の天然 の同調現象によるものがあり、例えば、 ニューロンが協調的に発火（電気的興 奮）して思考や動作につながるシグナ ルを発することなどがあると、彼は指 摘する。「将来的には、脳のペースメー カーの設計、細胞が近隣細胞を同調さ せる仕組みや同調しなくなることで何 らかの病的状態に陥る仕組みの解明な どが可能になるかもしれません。発振 の同調は、生物学において実際に非常 に重要なものなのです」。

Hastyによれば、今回、そうした天然 の回路に関して非常に興味深いことが明 らかになったという。それは、複雑な活 動パターンを作り出すのに複雑な回路は 必要ない、ということだ。「2 種類の遺 伝子から、これだけの複雑さを作り出せ るのです。今回の成果は、複雑な挙動に 多数の遺伝子は必要ないことを物語って います」と Hasty は話している。

(翻訳 : 船田晶子)

\footnotetext{
1. Danino, T., Mondragón-Palomino, O., Tsimring, L. \& Hasty, J. Nature 463, 326-330 (2010).

参考動画

http://www.youtube.com/watch?v=pnjdAr4EjIO
} 